\title{
Review
}

\section{9 theses on the reevaluation of value. A postcapitalist manifesto}

\author{
Brian Massumi \\ University of Minnesota Press, Minneapolis, 2018, \\ 152pp., ISBN 978-1-5179-0587-3
}

Contemporary Political Theory (2020) 19, S263-S266. https://doi.org/10.1057/s41296019-00352-w; published online 1 October 2019

In the mid-eighties and thus before the collapse of the Soviet Union, Alain Badiou published a booklet addressing the then-already unfolding crisis of Marxism. His suggestion was that what was needed was a new Communist Manifesto. He thus called for a repetition of the very founding gesture of Marxism in its nineteenth century and then twentieth century version, accounting for - but not invalidated by - its practical failures and misadventures. Badiou thereby pointedly repeated the claim that Marx and Engels themselves made in the preface to the 1872 edition of the Manifesto - wherein they identified it as a 'historical document', which they already had lost the 'right to alter', indicating that the Manifesto had become the transhistorical property of mankind.

In 2018, Brian Massumi published a short book that can be read as an attempt to take up the difficult task formulated by Badiou and anticipated by Marx and Engels. Even though it does not make any explicit reference to the Communist Manifesto, it is a 'manifesto' that shares with Marx and Engels's text its open emancipatory aim. Massumi presents his manifesto in almost one hundred (99) theses. Therein, he attempts to update not only its predecessor but Marxism itself - if we for a moment grant that this is the name for the thought of emancipation - on a vast number of economic, ideological and political issues.

The main aim of Massumi's manifesto is to give an answer to a highly complex question: how to conceive and imagine the transition out of capitalism. How to imagine what comes 'after'? This 'after' is a state, or maybe not a state, or time that Massumi does not directly identify as 'communist', but rather speaks of it in a determinately indeterminate manner. His name for it is 'postcapitalism', and he seeks affirmatively to defend the very possibility of there being an 'after' of capitalism at all.

Massumi's manifesto has set its own task: it must tell its reader what 'postcapitalism' is, and it must tell its reader how to get there. The Marxist tradition accounted for the transition - if it is one - out of capitalism in quite diverse terms

(c) 2019 Springer Nature Limited. 1470-8914 Contemporary Political Theory Vol. 19, S4, S263-S266 
(which I will not recall here). Massumi's does so, too. His concept of transition is that of the 'revaluation of value'.

This slightly Nietzschean sounding idea - note that Massumi's aim is not a transvaluation of all values - constitutes the practical aspect of his proposal. He suggests making a different use of value. In Marx, classically, anything that appears as a commodity is determined by an exchange value and by a use-value. Massumi aims to make a different use - bringing out a different use-value - of the very component of value (that splits into use value and exchange value). So, how to reevaluate value?

Massumi takes up a classical critical trope, namely that capitalism misevaluates. What does it misevaluate? Life. Why does it misevaluate life? Life as such does not have an exchange value (nothing has), but it has for Massumi use-values (as everything has). Yet, because capitalism constantly externally assigns values to things irrespective of how these things themselves work, the value that capitalism assigns to life (or anything else) is not 'appropriate'. The value it assigns to life is not derived from the immanence of a lived life, and capitalism even blocks life's own self-evaluation. Since capitalism constitutes value by relating things externally to one another through exchange, capitalism misevaluates life.

A symptom of this phenomenon is the function money plays in capitalism as expression of value. Money's expression of value is constitutively reductive - and even the use we make of money in capitalism is reductive as we treat it solely as a reductive means of expressing exchange value. However, how to evaluate in more appropriate terms? How to come up with a more adequate understanding of money? By employing a different means or medium of evaluation, notably, an immanent one.

This medium is provided by what Massumi calls (with a clear Spinozist resonance) affect. Affects evaluate life in the very act of living - affects are lived life - and they are inherently so multiple and singular that they represent the multiplicity of life's creative potential: all the shades, not only of grey, but also of sadness and happiness. Affect as basis for valuation breaks with what Massumi calls the 'myth of equal exchange' (p. 6) - which is mythical - because any exchange that would actually exchange equal things would by definition no longer be an exchange.

Equal exchange is mythical or fictitious, exchange inherently presupposes inequality. If one seeks to evaluate differently, one must evaluate on the basis of difference and singularity, not of identity. How to do this? By really grasping what life is already doing (and it is important to note that capitalism is alive and/as well).

The philosophical point here is that one must remind oneself of the fact that value is always the result of a process of evaluation, i.e. of making a difference. Difference always implies the production of difference, since it is not a given. There is hence a surplus of action over status, of activity over passivity, of difference over identity, of practice over stasis. This is already and quite simply 
because there is no value without an act of evaluation (or exchange in classical terms).

Yet, and this is what capitalism thrives on, this more-than-value can be expressed in terms of value, as surplus-value. And it is clear that capitalism thrives on the production of surplus-value. However, surplus-value is really the index of another surplus, a surplus in the surplus. There is a surplus to and of value, a surplus-value of surplus-value. And this surplus must thus be linked to the production of difference, and not to the production of commodities.

So, capital misevaluates because it can only sustain itself through the production of surplus-value. However, at the same time, it incarcerates the surplus in a reductive and restrictive form of value. This works inter alia through the implementation of a regime of time: capital organizes our life time. The reevaluation of value that Massumi proposes reevaluates this surplus by accounting for the very source of value.

To render this in more classical terms: capital relies on something that it must eliminate. It is thus fundamentally contradictory. It is inter alia a system of production that relies on a productive force - on a productive process in Massumi's terms - that it can only make an exploitative use of, an ab-use. This productive force is life, and this is where Massumi differs from Marx. The implication is that all of us living under capitalism are complicit in it (p. 68).

Taking this into account, Massumi seeks to mobilize the creative potential of life that makes up what he calls a 'life-value' (p. 20) - suggesting 'don't bemoan complicity - game it' (p. 69). Capitalism already does so, because it alters life and thus shows how life can be creatively altered. However, because capitalism restricts the modes of alteration, it deadens life in the act of mobilizing it. Massumi wants a surplus of life-mobilization: (the) More (of) life. It is about being alive as intensively as possible (hence the focus on affect).

Unfortunately, I do have to leave out many aspects of Massumi's argument. One might read him as arguing that if capitalism is all about production (notably about the production of subjects that are in conformity with it), this production can be turned against it. We thus have to conceive of a 'post-man' (p. 77) that effectively alters our understanding not only of what it means to be human but also what it means to be alive. Since to be alive - even though life is all about production and creativity - is itself a gift (p. 120), a gift that we do not have to pay back ('freed from the dialectic of the countergift' (p. 120), an inherently a-capitalist gift. Hence, for him, life is a-capitalist productivity.

As a reader of this book, I mainly have two questions.

The first one concerns the - quite familiar within the Deleuzian universe - idea that life is a gift, productive and creative and, well, good. Is life not at least as much the opposite of this? A burden? A gift one would have never asked for? Think of the age-old trope of not being born as the greatest achievement... How to factor this ambivalence over life's goodness into the account of capitalism (and of

(C) 2019 Springer Nature Limited. 1470-8914 Contemporary Political Theory Vol. 19, S4, S263-S266 S265 
overcoming it)? Would this not fundamentally alter the perspective of the whole proposal?

The second one concerns the absence of any reference to the practical history of Marxism and Communism in this book. Is there nothing to be learnt from previous attempts to realize an idea of 'postcapitalism'? Might it not help to take into account what happened in Russia or China? Or does contemporary capitalism even provide us with the measure for what we think of 'postcapitalism'?

This is a great read, full of extremely productive ideas and very engaging concepts. In this book, Massumi launches an open invitation for many serious and difficult discussions to take place.

Publisher's Note Springer Nature remains neutral with regard to jurisdictional claims in published maps and institutional affiliations.

Frank Ruda Dundee University, Dundee DD1 4HN, Scotland, UK f.ruda@dundee.ac.uk 